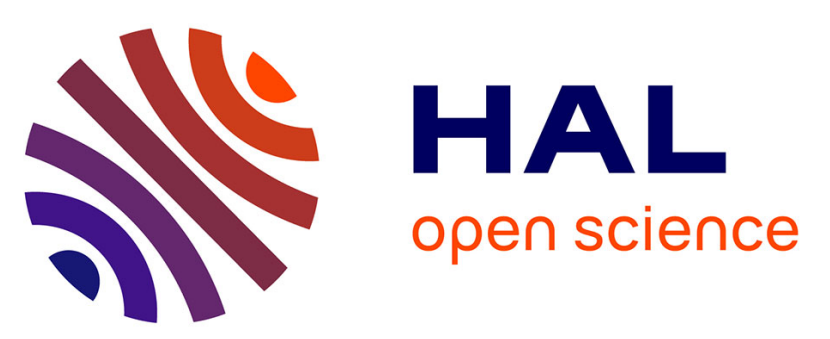

\title{
The nonglacial diamictite of Toutswemogala Hill (lower Karoo Supergroup, central Botswana): Implications on the extent of the late Paleozoic ice age in the Kalahari-Karoo Basin
}

\author{
Pierre Dietrich, Fulvio Franchi, Larona Setlhabi, Rose Prevec, Marion
}

Bamford

\section{To cite this version:}

Pierre Dietrich, Fulvio Franchi, Larona Setlhabi, Rose Prevec, Marion Bamford. The nonglacial diamictite of Toutswemogala Hill (lower Karoo Supergroup, central Botswana): Implications on the extent of the late Paleozoic ice age in the Kalahari-Karoo Basin. Journal of Sedimentary Research, 2019, 89 (10), pp.875-889. 10.2110/jsr.2019.48 . hal-02363921

\section{HAL Id: hal-02363921 \\ https://hal.science/hal-02363921}

Submitted on 14 Nov 2019

HAL is a multi-disciplinary open access archive for the deposit and dissemination of scientific research documents, whether they are published or not. The documents may come from teaching and research institutions in France or abroad, or from public or private research centers.
L'archive ouverte pluridisciplinaire HAL, est destinée au dépôt et à la diffusion de documents scientifiques de niveau recherche, publiés ou non, émanant des établissements d'enseignement et de recherche français ou étrangers, des laboratoires publics ou privés. 


\title{
THE NONGLACIAL DIAMICTITE OF TOUTSWEMOGALA HILL (LOWER KAROO SUPERGROUP, CENTRAL BOTSWANA): IMPLICATIONS ON THE EXTENT OF THE LATE PALEOZOIC ICE AGE IN THE KALAHARI-KAROO BASIN
}

\author{
PIERRE DIETRICH, ${ }^{1,2}$ FULVIO FRANCHI, ${ }^{3}$ LARONA SETLHABI, ${ }^{3}$ ROSE PREVEC, ${ }^{4,5}$ AND MARION BAMFORD ${ }^{6}$ \\ ${ }^{1}$ Department of Geology, P.O. Box 524, Auckland Park Kingsway Campus, University of Johannesburg, Johannesburg 2006, South Africa \\ ${ }^{2}$ Géosciences-Rennes, UMR6118, Université de Rennes 1, 35042 Rennes Cedex, France \\ ${ }^{3}$ Department of Earth and Environmental Science, Botswana International University of Science \& Technology (BIUST), Private Bag 16, Palapye, Botswana \\ ${ }^{4}$ Department of Earth Sciences, Albany Museum, Somerset Street, Makhanda 6139, South Africa \\ ${ }^{5}$ Botany Department, Rhodes University, P.O. Box 94, Makhanda 6140, South Africa \\ ${ }^{6}$ Evolutionary Studies Institute, 1 Jan Smuts Avenue, Braamfontein, University of the Witwatersrand, Johannesburg 2000, South Africa \\ pierre.dietrich@univ-rennes1.fr
}

\begin{abstract}
Along the easternmost edge of the Karoo-Kalahari Basin (KKB) of Botswana, the Toutswemogala Hill succession exposes a 30-50-m-thick suite of siliciclastic deposits interpreted by some as glaciogenic in origin tied to the Permo-Carboniferous Late Paleozoic Ice Age (LPIA). Six facies associations (FA) were recognized in this succession, resting unconformably on a highly uneven Archean gneissic basement, and consisting from base to top of: 1) clastsupported breccia made up of angular cobbles and boulders ubiquitously derived from the underlying basement, 2) well-bedded siltstones sealing or locally interdigitated with the underlying breccia, and bearing abundant remnants of Glossopteris sp. leaves, 3 ) a chaotic to faintly laminated matrix-supported diamictite bearing angular and subrounded clasts and tree logs attributed to the genus Megaporoxylon, 4) cross-bedded conglomerate bearing well-rounded quartz and clasts, 5) planar-laminated to ripple-laminated, poorly sorted, muddy sandstones showcasing dispersed mud chips that grade upward into 6) poorly sorted, cross-bedded coarse-grained sandstones displaying convolute beds and abundant imprints of unidentifiable tree logs.

No evidence of glaciogenic processes have been found in this succession, in the form of either pavement or clasts striations. The breccia and diamictite are interpreted as scree and mass-flow deposits, respectively. Along with the age of the deposits, inferred from the plant debris (upper Carboniferous to lower Permian), the stratigraphic position of this sedimentary succession resting on the Archean basement suggests that it corresponds to the Dukwi Formation, a stratigraphic equivalent of the Dwyka Group in the Main Karoo Basin. This would explain the resemblance of the facies to those recovered at the base of the central Kalahari-Karoo Basin and in the neighboring Tuli, Ellisras, and Tshipise basins. The absence of diagnostic criteria for glacial processes in the studied succession raises the question of the extent, in both time and space, of the LPIA-related ice masses over southern Africa and particularly in southeastern Botswana. It is suggested here that during this glacial epoch, spatially restricted ice masses were confined in bedrock valleys (valley glaciers) in an uplifted setting otherwise characterized by non-glaciogenic processes, further strengthening the scenario of fragmented ice masses over southern Gondwana.
\end{abstract}

\section{INTRODUCTION}

Diamictite is defined as "a non-sorted terrigenous lithified sedimentary rock containing a wide range of particle sizes" (Bell et al. 2016). The recognition and hence correct interpretation of diamictite in the geological record has long been a source of controversy for sedimentologists (e.g., Visser 1994; Eyles and Januszack 2007; Soreghan et al. 2009; Le Heron et al. 2017; Vesely et al. 2018), yet is crucial for paleoenvironmental and climatic reconstructions. While a glaciogenic origin is commonly invoked to interpret such facies (tillite, grounding-zone wedges, rain-out under an ice shelf), they may also constitute the product of a wide range of nonglaciogenic sedimentary processes such as subaqueous sediment gravity flows and subaerial alluvial and colluvial fans or debris flows, among others (e.g., Fedorchuk et al. 2018). To further complicate the interpretation of these deposits, diamictite may also result from resedimentation through non-glaciogenic processes, of initially glaciogenic deposits (Caron et al. 2011; Le Heron et al. 2017; Kennedy et al. 2019).

Diamictites have been extensively recognized at the base of Karoo-age basins (Carboniferous-Jurassic) across sub-Saharan Africa (Fig. 1; Haughton 1963; Isbell et al. 2012; López-Gamundi and Buatois 2010; Craddock et al. 2019). In southern Africa, these poorly sorted sediments are most frequently characterized as Permo-Carboniferous glaciogenic deposits tied to the Late Paleozoic Ice Age (LPIA), and are formalized as the Dwyka Group, forming the basal unit of the Karoo Supergroup (e.g., Visser 1989; Catuneanu et al. 2005; Herbert and Compton 2007; Isbell et al. 2008a; Stollhofen et al. 2008). The correct interpretation of these widespread deposits is therefore crucial for the reconstruction in both time 

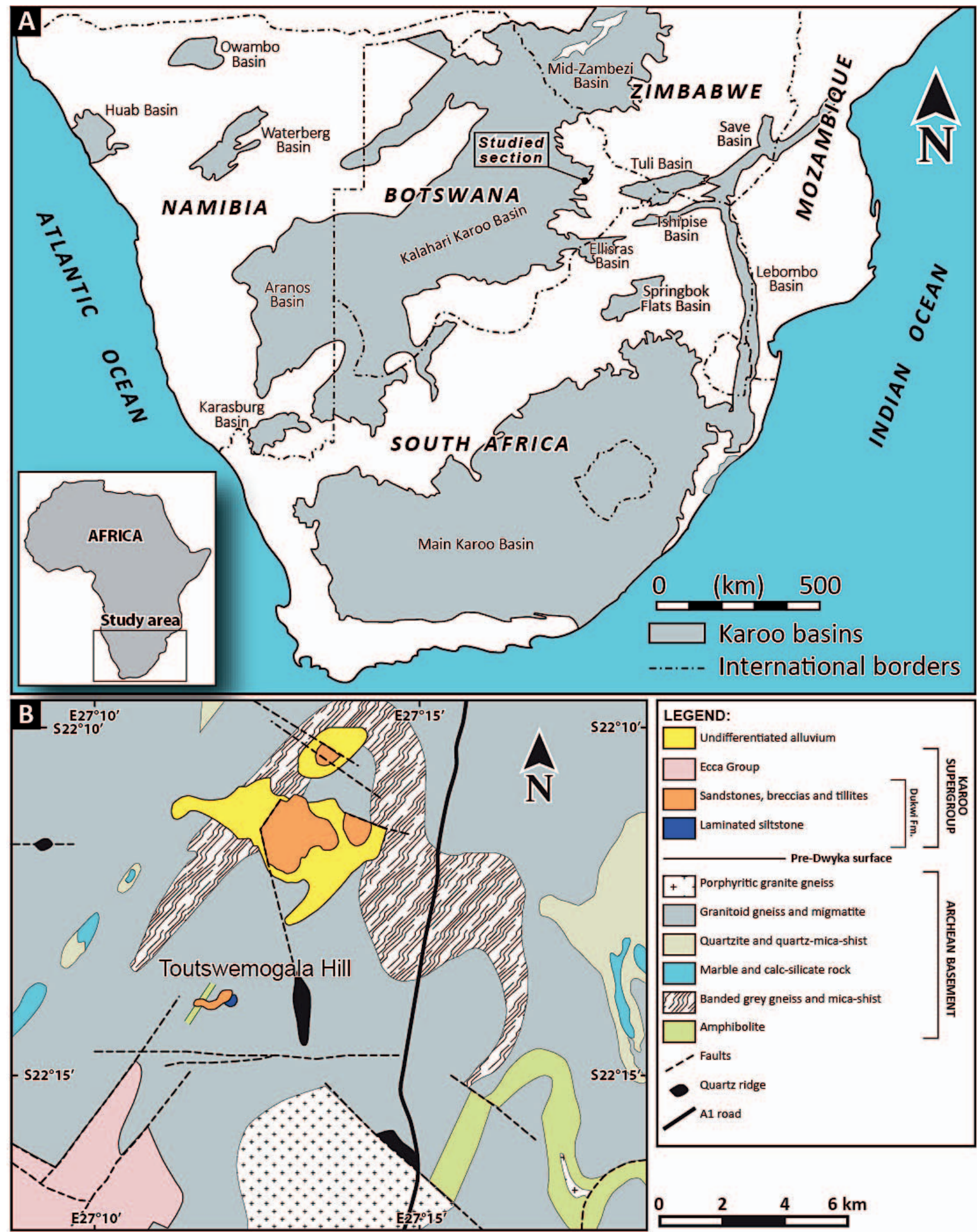

FIG. 1.-A) The Karoo-aged basins of southern Africa. The study site in the Kalahari-Karoo Basin (KKB) of Botswana is indicated. Modified after Catuneanu et al. (2005). B) Schematic geological map of the Toutswemogala Hill area (see Part A for location). Modified from Key and Golding (1994). 
and space of the LPIA across southern Gondwana (e.g., GonzálezBonorino and Eyles 1995; Visser 1997; Bordy and Catuneanu 2002; Fielding et al. 2008; Dietrich and Hofmann, in press).

Diamictite deposits have been reported in southeast Botswana in the Toutswemogala Hill area (Fig. 1). In his precursor book, Du Toit (1954) recognized the lack of glaciogenic features in this diamictite, but in more recent times, these sediments have been interpreted as glacial deposits (tillite) tied to the LPIA (Modie 2002) and are portrayed as such in the most recent geological map of Botswana (Fig. 1B; Key and Golding 1994). The paucity of thorough sedimentological analyses has allowed the perpetuation of the unsupported glaciogenic interpretation of the deposits, and university students are regularly taken to visit the site to appreciate the spectacular "tillite." The aim of this paper is to present, for the first time, a detailed sedimentological and petrographic characterization of the sediments of the Toutswemogala Hill. The analysis of this new data set in the regional context of the Kalahari-Karoo Basin (KKB), sheds light on the paleoenvironmental conditions at the time of deposition and has highlighted the absence of solid criteria for glacial processes in these central Gondwanan terrains. This will provide further constraints on the modalities and timing of the LPIA in the region.

\section{GEOLOGICAL SETTING}

The KKB, which stretches from southeast Namibia through Botswana and into Zimbabwe, encompasses a kilometer-thick Karoo-age sedimentary succession (the Karoo Supergroup) that was deposited during Late Carboniferous to Early Jurassic times (Fig. 1A; Visser 1997; Scheffler 2004; Catuneanu et al. 2005). The stratigraphy of the Karoo Supergroup in the $\mathrm{KKB}$, as in many of the other Karoo-age basins of southern Africa (Haughton 1963; Johnson et al. 2006; Guillocheau 2018) records a basinal evolution ranging from a glacial period through fluvio-deltaic, lacustrine, and ultimately arid continental settings before the extrusion of widespread flood basalts linked to the break-up of Gondwana. This evolution is represented by a dominantly siliciclastic sedimentary sequence ranging from glacial diamictites of the Dwyka Group and correlative units, to a succession of fluvio-deltaic and lacustrine sandstone and mudstone belonging to the Ecca Group, and fluvio-lacustrine siltstone and mudstone facies of the Beaufort Group that gives way to the fluvial and aeolian red beds of the Stormberg Group. The whole sequence was capped in the Early Jurassic by the basalt lava flows of the Drakensberg Lava Group. The KKB has been interpreted as the backbulge area of flexural subsidence associated with the uplift of the Cape Fold Belt (Catuneanu 2004) although such interpretation remains controversial (Pysklyweck and Mitrovica 1999).

The correlative of the basal Dwyka Group in the Botswanan KKB is locally subdivided into the Malogong and Khuis formations or formalized as the Dukwi Formation (Smith 1984). The Dukwi Formation in the center of the basin consists of diamictite and thinly laminated siltstones that lie unconformably on pre-Karoo topography and have been interpreted as tillites and varvites, respectively (Smith 1984; Bordy 2013). Rare exposures of the Dukwi Formation occur along the eastern edge of the $\mathrm{KKB}$ and mainly comprise massive diamictite, locally interbedded with thin lenses of sandstone and laminated siltstone (Modie 2007). A complete section allegedly attributed to the Dukwi Formation is exposed at Toutswemogala Hill (Figs. 1, 2; Key and Golding 1994; Modie 2002; Modie and Le Hérissé 2009). Toutswemogala Hill (hereafter referred to as "the Hill"), located in the Central District of Botswana about $50 \mathrm{~km}$ north of Palapye Village (Fig. 1), is an elongated flat-topped hill protruding from the flat-lying topography of the Kalahari plain (Fig. 2). In the study area, the Karoo series rest unconformably on a basement consisting of highgrade metamorphic and igneous Archean rocks (e.g., gneiss, granite, rhyolite, gabbro, migmatite, quartzite, and mica schist) of the Zimbabwe and Kaapvaal cratons and Limpopo Mobile Belt suites (Fig. 1B; see Aldiss
1991 for a review) and the siliciclastic deposits of the Proterozoic Palapye Group (Mapeo et al. 2004). The present research focuses on the stratigraphic succession of the Hill, comprising diamictites and breccias unconformably overlying gneissic basement rock and in turn overlain by coarse siliciclastic deposits.

\section{MATERIALS AND METHODS}

Four high-resolution stratigraphic sections were measured at outcrops along the Hill, across an interval of $850 \mathrm{~m}$ (Fig. 3). Facies analysis included observations of grain size, sorting, sedimentary structures, fossil content, paleocurrents, geometries of the sedimentary bodies, and stratigraphic relationships with underlying, overlying, and adjacent units. Samples for petrographic studies were collected and thin sections prepared at the University of Johannesburg. Two thin sections of fossil wood were prepared and described at the University of the Witwatersrand. To obtain a statistically sound composition of the coarse-grained facies, namely the breccia (FA1), the diamictite (FA3), and the conglomerate (FA4), a total of eight $1 \mathrm{~m}^{2}$ grids were point-counted at $10 \mathrm{~cm}$ intervals (after Bechstädt et al. 2009). The lithology in the middle of each square was described and then the average composition for all of the combined squares was calculated. Ternary diagrams were used to present the data (Fig. 4). For the sake of clarity, the term "tillite," which implies a certain degree of interpretation, is here substituted with the purely descriptive term "diamictite" (Moncrieff 1989; Bell et al. 2016).

\section{FACIES ASSOCIATIONS AND DEPOSITIONAL ENVIRONMENTS}

Six facies associations (FA), laterally juxtaposed or vertically superimposed, have been discriminated in the Hill succession. Figure 3 illustrates the thickness of the various units as well as their stratigraphic relationships. Where relevant, information about clast composition and plant material recovered is included in the facies descriptions as they are important for interpretation of the depositional environments. In the study area, the basement upon which the studied succession lies consists of Archean pinkish to reddish granitoid gneiss and layered grayish to greenish gneiss locally crosscut by small quartz veins and quartzite (Fig. 1B). The top surface of the basement is highly uneven (Figs. 2, 3). No evidence of glacial processes such as striae, grooves, or polished surfaces was found on the basement rock at the contact with the overlying strata. In places, the basement surface shows evidence of chemical weathering processes that must have occurred before deposition of the overlying strata. Therefore, relief in the basement probably represents the paleotopography before deposition of the overlying strata.

\section{FA1: Clast-Supported Breccia, Colluvial Apron}

Description.-Facies association 1 (FA1) rests unconformably on the basement and fills some paleotopographic lows where the maximum observed thickness is ca. $10 \mathrm{~m}$ (Fig. 3). This FA consists of a clastsupported breccia bearing pinkish to reddish granitoid gneiss clasts derived exclusively from the immediate underlying basement (Figs. 4, 5A, B). Clasts are angular to subangular and range from pebble to boulder in size. The breccia is massive without any stratification or vertical or horizontal grain sorting. The contact between the weathered basement granitoid gneiss and the overlying clast-supported breccia is also uneven, and as such, portrays the general trend of the underlying topography of the basement. This FA pinches out against the steep slopes of the basement. The top of this facies is dipping downslope at ca. $30^{\circ}$. The mean size of the clasts gradually decreases away from basement high slopes, from boulders to cobbles and pebbles where thin $(<50 \mathrm{~cm})$ breccia horizons are interdigitated with well-bedded siltstones (FA2; Figs. 3, 5C). 

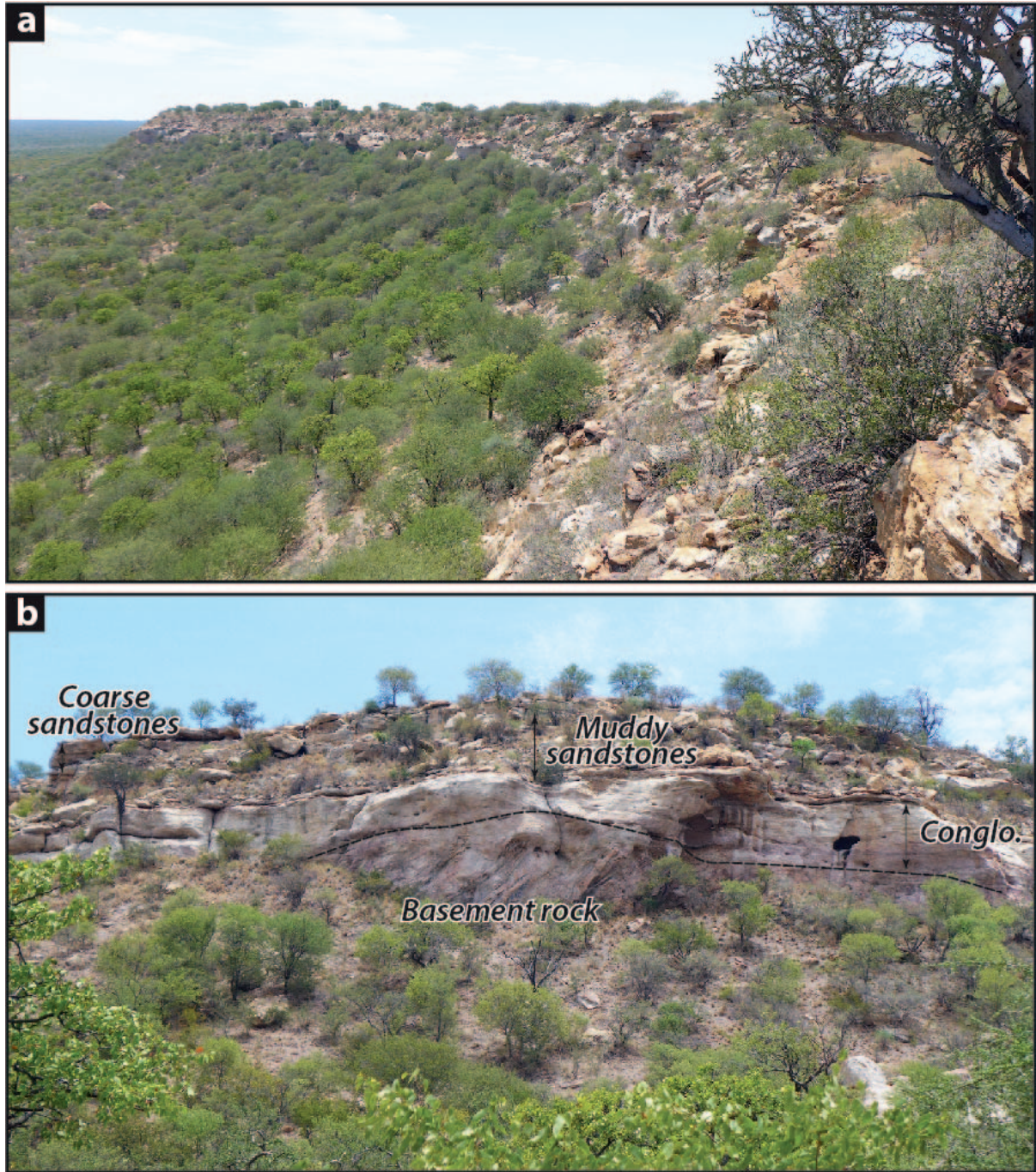

Fig. 2.-Panoramic views of Toutswemogala Hill (see Fig. 1B for exact location). A) The flattopped Toutswemogala Hill forming 30-50-m high relief on the Kalahari plain (Quaternary sand) seen in the background. B) A paleotopographic high formed by the basement rock overlain by cross-bedded conglomerate (FA4), muddy sandstones (FA5), and coarse-grained, cross-bedded sandstones (FA6) forming the top of the succession. Note that the breccia (FA1), rhythmically bedded sandstone (FA2), and diamictite (FA3) facies are not displayed in this section as they are found only in paleotopographic lows (see Fig. 3).
Interpretation.-The clasts characterizing this lowermost FA are angular and derived exclusively from the nearby paleotopographic highs and slopes. These clasts solely originate from the disaggregation and resedimentation of the basement itself with no apparent contribution from other sources (Fig. 4), and with minimal (a few meters to tens of meters) transportation as indicated by their high immaturity. As this unit drapes the basement slope and has a chaotic structure, with no evidence of the contribution of water to transport and deposition (Fig. 5A, B), it is suggested that these deposits correspond to colluvial or scree-slope apron deposited by rock falls or avalanches along the steep, collapse-prone slopes of a marked, still visible paleotopography (Fig. 2; Goudie 2004). The observed slope formed by the upper contact of this unit $\left(30^{\circ}\right)$ may therefore represent the angle of repose for coarse deposits of this nature (Froehlich 2011). Although no intrinsic, diagnostic criterion has been found to attribute this deposit to a subaerial or subaqueous setting, we suggest that the presence of FA2 (wellbedded, fine-grained sandstones and siltstones interpreted as lacustrine deposits, see below) interdigitating with and sealing these scree-slope deposits, would indicate that the deposition occurred underwater.

\section{FA2: Well-Bedded Fine-Grained Sandstones and Siltstones, Lacustrine Deposits}

Description.-This facies association consists of an alternation between fine-grained sandstone (centimeter thick) and siltstone (millimeter thick) beds (Fig. 5C, E). The FA2 shows strong lateral discontinuity as it is found blanketing the underlying FA1 (Fig. 5B, D, E) within the paleotopographic lows (Fig. 3). FA2 paraconformably drapes FA1, onlaps onto its flanks, and is occasionally interdigitated with its finer-grained distal reaches (Figs. 3, 5C). These well-bedded sandstones and siltstones line the upper side of the FA1 boulders locally, giving rise to subvertical lamination (Fig. 5B). A maximum thickness of $3 \mathrm{~m}$ has been observed in the centers of some paleotopographic lows (Fig. 3) although the lower stratigraphic contact was not observed here. Where the contact with the underlying breccia is exposed, a thickness of only a few tens of centimeters of well-bedded sandstones and siltstones wedging out over paleotopographic highs was observed (Fig. 3). Where interfingered with the distal reaches of the FA1, the FA2 siltstones show occasional current ripples and/or wave ripples (Fig. $5 \mathrm{~F})$.

FA2 preserves abundant remnants of fossil leaves (Fig. 5G, H). The leaf impressions show parts of entire-margined, possibly elliptic to elongate leaves attributable to Glossopteris, with finely bifurcating and anastomosing veins originating from a single pronounced midrib (Fig. 5G), as well as glossopterid forms with less distinct medio-longitudinal vein aggregations typically referred to Gangamopteris (Fig. 5H). Some leaf fragments of either Noeggerathiopsis or Palaeovittaria are also present in the assemblage, although the very poorly preserved secondary venation, and the absence of leaf bases showing patterns of vein origination, hinder more 


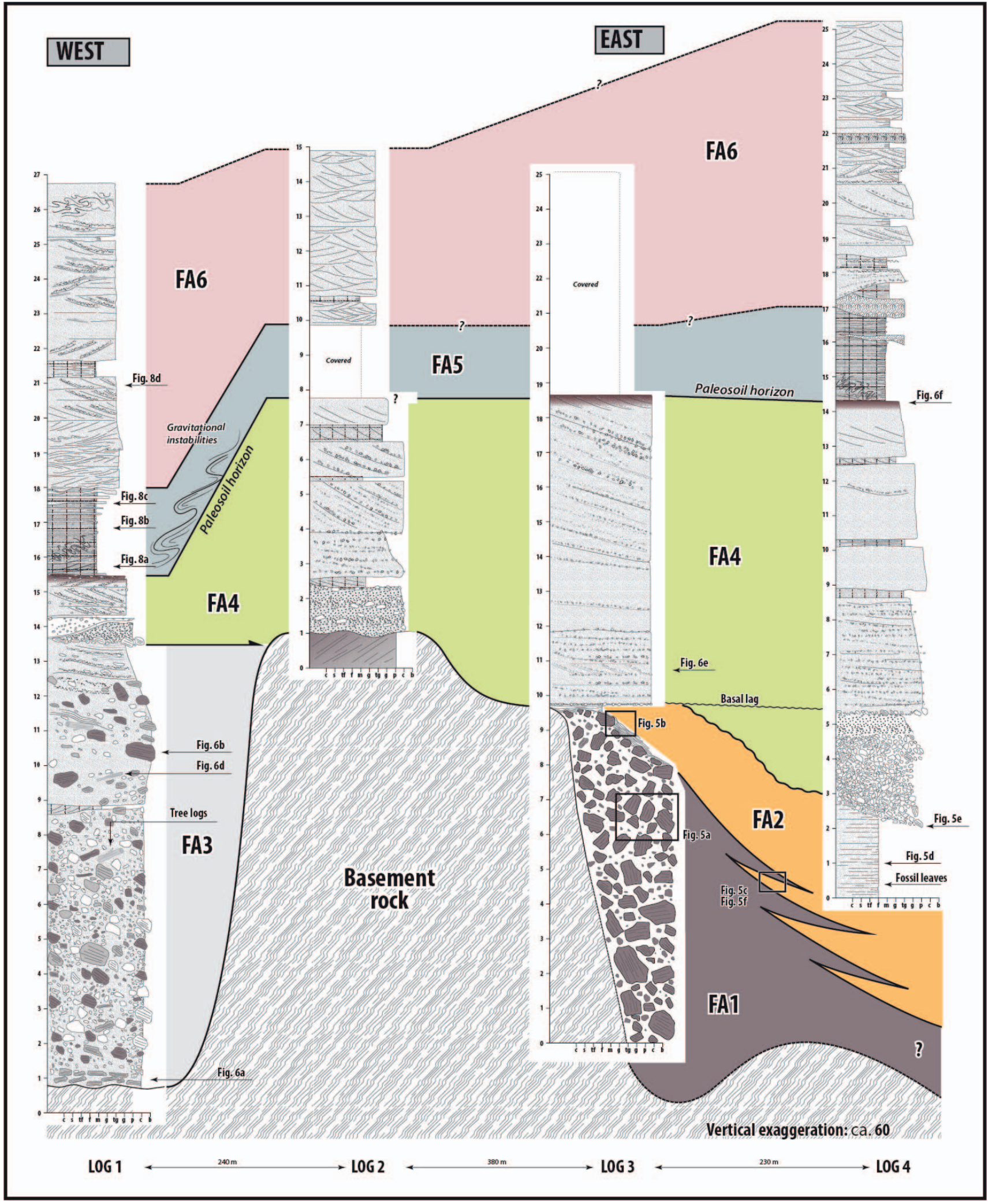

FIG. 3.- Sedimentary logs and stratigraphic architecture of Toutswemogala Hill. Facies and architecture are described in the text. 


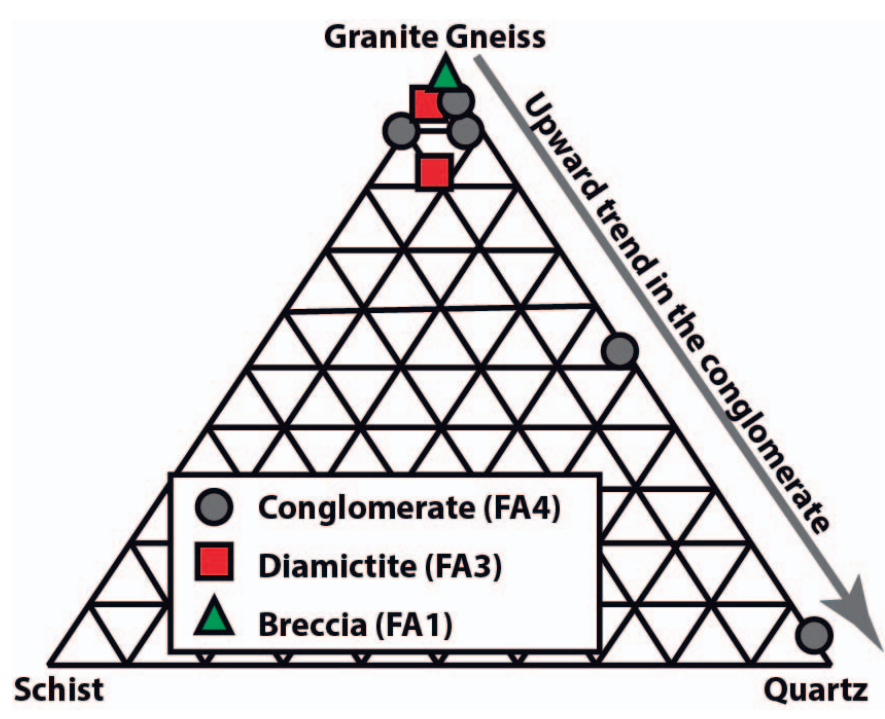

FIG. 4.-Ternary diagram (schist-granite gneiss-quartz) showing the composition of the breccia (FA1), diamictite (FA3), and conglomerate (FA4).

precise identification. In both of these form genera, elongate-elliptica leaves have narrowly bifurcating, almost parallel venation, with few to no anastomoses. All of the above leaf forms are typical of the Late Carboniferous to Early Permian fossil floras preserved in the Main Karoo Basin (Plumstead 1969; Anderson and McLachlan 1976; Anderson and Anderson 1985).

Interpretation.- - These deposits occur confined between bedrock and or the flanks of FA1 in paleotopographic depressions, suggesting a depositional environment constrained by the paleotopography itself. The well-developed bedding observed in this facies of alternating siltstones and fine-grained sandstones might represent rhythmite deposits, and taken together with the confined nature of this unit, suggests a lacustrine environment. Abundant plant debris found in this unit may indicate the occurrence of hyperpycnal flows originating from a plunging river efflux (Zavala et al. 2010) more likely to occur in a lacustrine setting. The interdigitating between scree-slope (FA1) and lacustrine (FA2) deposits indicates that both facies were deposited concomitantly. The wrapping of boulders (Fig. 5B) in the sandstone beds indicates that settling likely played a significant role in the deposition of these fine-grained deposits and their local subvertical geometry, although compaction during diagenesis may have also contributed to such geometries.

\section{FA3: Matrix-Supported Diamictite, Subaqueous Mass-Flow Deposits}

Description.- The third facies association (FA3), up to $15 \mathrm{~m}$ in thickness, also lies directly on the basement rock in the centers of paleotopographic lows, away from slope of the basement, where FA1 and FA2 are absent (Fig. 3). This lithofacies consists of a matrix-supported diamictite made up of a chaotic to faintly laminated assembly of subrounded to angular pebbles, cobbles, boulders, and silicified logs (Fig. 6A-D). The matrix consists of poorly sorted, fine- to coarse-grained silty sand made up of quartz grains cemented by clay minerals and silica (equivalent to the clast-rich intermediate diamictite of Moncrieff 1989). Overall, the diamictite unit shows a general fining-upward trend expressed both by the decreasing mean grain size in the matrix and by a decreasing proportion and size of the clasts. Clasts are mostly ( $>80 \%)$ locally derived pink to green granite and gneiss (Fig. 6A-C); rounded quartz, quartzite, and schist clasts are extremely rare (Fig. 4). Discontinuous sandstone lenses showing faint cross-stratification occur throughout this diamictite unit (Fig. 3). At the very base of the unit, angular gneissic clasts were conspicuously ripped up from the underlying bedrock and show no evidence of transport, implying erosion and in situ deposition (Fig. 6A).

Of particular interest is the presence in this diamictite of segments of silicified tree logs attributed to the genus Megaporoxylon cf. M. kaokense Kräusel of Carboniferous to Early Permian in age (Figs. 6D, 7; Kräusel 1956; Bangert and Bamford 2001; Stollhofen et al. 2008; Bordy 2018). The silicified wood is the secondary xylem of a gymnosperm tree with no pith preserved. The secondary xylem growth rings are very narrow and variable in diameter, ranging from $0.2 \mathrm{~mm}$ to $2 \mathrm{~mm}$ wide, with variable proportions of latewood tracheids and up to four traumatic rings in one growth ring (Fig. $7 \mathrm{~A}-\mathrm{C}$ ). The tracheids are squarish in outline, with comparatively thick walls and deposits of a dark substance in the lumens (Fig. 7B). Rays are uniseriate and 7-10-20 cells high (Fig. 7D); tracheid bordered pits are biseriate, alternate and contiguous, $10-15 \mu \mathrm{m}$ in diameter (Fig. 7E); cross-field pits are oopores and $15 \mu \mathrm{m}$ in diameter, but poorly preserved (Fig. 7F). Based on these anatomical features the wood belongs to the genus Megaporoxylon (Bangert and Bamford 2001) and is most similar to Megaporoxylon kaokense, but as the pith is not preserved the species identification is tentative.

Interpretation.-The discrimination between glaciogenic and nonglaciogenic diamictite can be problematic (e.g., Visser 1994; Eyles and Januszack 2007; Le Heron et al. 2017; Vesely et al. 2018; Kennedy et al. 2019). Most of the clasts found in this FA appear to be locally derived (pink to green granite and gneiss; Figs. 4, 5). Striated and/or faceted clasts have not been observed, although it is acknowledged that coarsegrained lithologies, which are less likely to mark and preserve glacial striation (Dowdeswell et al. 1985), dominate. However, the absence of striations on clasts, combined with their local origin, suggests that the diamictite does not originate from glaciogenic processes. The chaotic aspect of the deposits and the normal grading, rather point toward a scenario whereby successive debris, mass, or hyperconcentrated flows deposited the sediments (e.g., Prior and Bornhold 1988; Mulder and Alexander 2001; Caron et al. 2011; Moxness et al. 2018; Kennedy et al. 2019). Basal shear at the base of the flow is evidenced by rip-up clasts which show virtually no displacement (Fig. 6A). The presence of crossstratified sandstone lenses as well as clast imbrication in this unit further indicates that the mass-flow events were interrupted by tractive currents. As this unit lies at the same stratigraphic level as the lacustrine deposits (FA2, see Fig. 3), we suggest that the parent flow was likely subaqueous and lacustrine, as also evidenced by the preservation of tree logs (Gastaldo and Demko 2011), although similar facies may also develop in subaerial environments (Soreghan et al. 2009). Although well rounded, clasts are mainly of local origin (granite gneiss, Fig. 4), indicating that the flow ran over a short distance. We suggest that some of the basement-rock collapse may have formed from scree-slope deposits (FA1) that developed into mass flows over distance through a rheology transformation (Sohn 2000).

The presence of allochthonous fossil leaves in lacustrine deposits (FA2), together with tree logs in these deposits, suggests the presence of Glossopteris forests regionally within the catchment area, where welldeveloped soils were supporting tree growth. It should be noted, however, that leaves, and particularly logs, can be transported for hundreds of kilometers (or thousands in the case of logs; see Ferguson 2005 and references therein). In the absence of fossilized roots and autochthonous fossil plant deposits in the study area, it is not possible to speculate further on the proximity of the vegetated areas. It is nonetheless interesting to note the very narrow growth rings observed in the logs as these imply adverse environmental conditions such as low water availability and/or low temperatures within a season, for example cold snaps or drought (e.g., Chaloner and Creber 1990). 

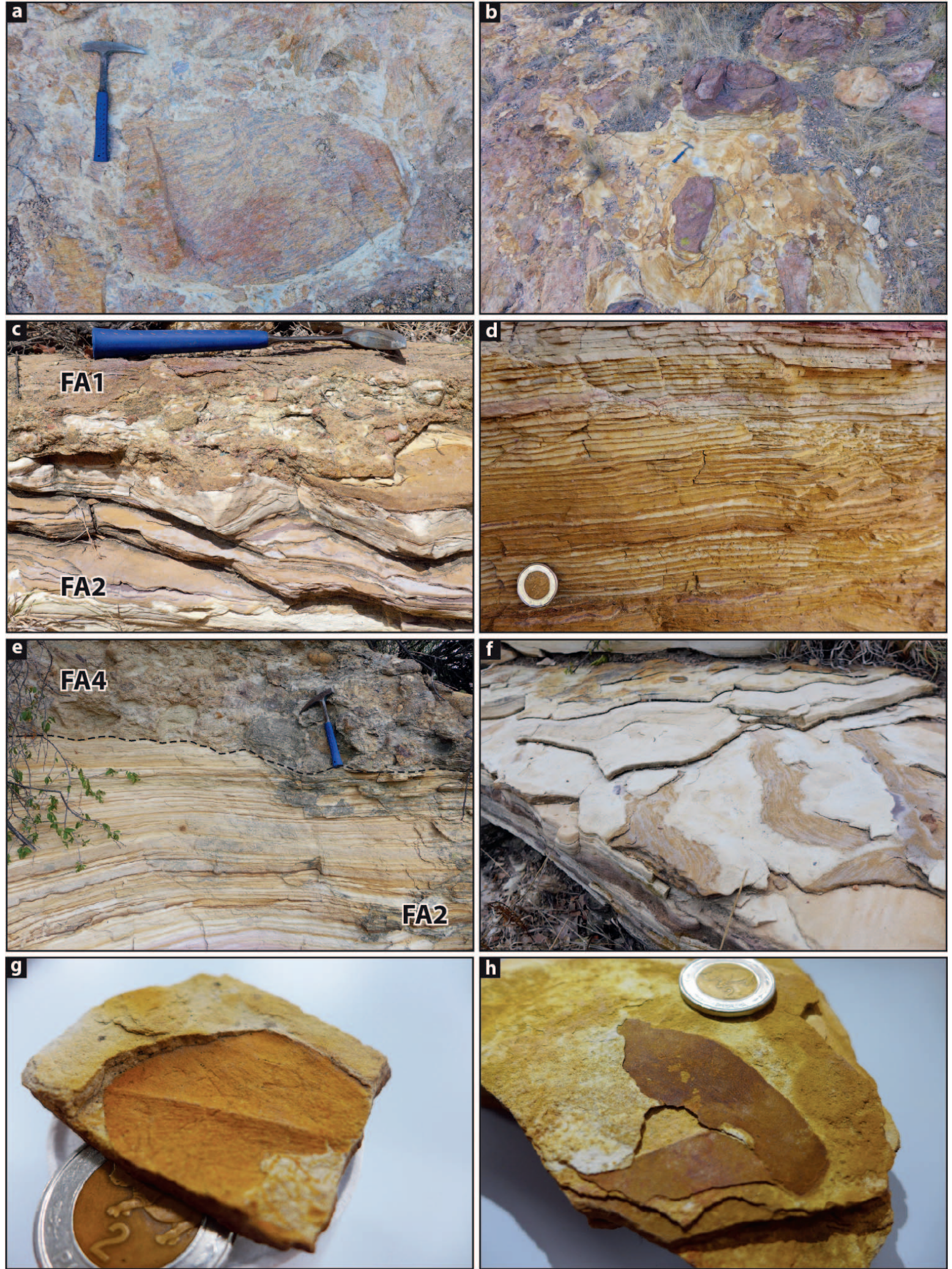

FIG. 5.-Outcrop view of the breccia $a_{2}$ rhythmically bedded sandstones, and examples of fossil leaves found in the sandstone. A) Clast-supported breccia (FA1) with angular, grain- to boulder-size clasts derived from the underlying granitoid basement rock. These deposits are interpreted as colluvial or scree-slope apron deposited as rock falls or avalanches along the basement slopes that formed the paleotopography. B) Angular boulders belonging to the breccia (FA1) wrapped into the rhythmically bedded sandstones (FA2). C) Contact between the finer-grained component of the breccia (FA1, top) and the well-bedded siltstones (FA2, bottom). D) A close-up view of well-bedded siltstones (FA2). E) Well-bedded siltstones (FA2) being eroded by the basal clast-supported, polymict conglomerate (FA4) here interpreted as subaerial debris or hyperconcentrated-flow deposits in a alluvial fan. F) Current ripples developed in the well-bedded siltstones (FA2). G) Glossopteris and H) Gangamopteris leaves sampled in well-bedded siltstones (FA2). See Figure 3 for location. 

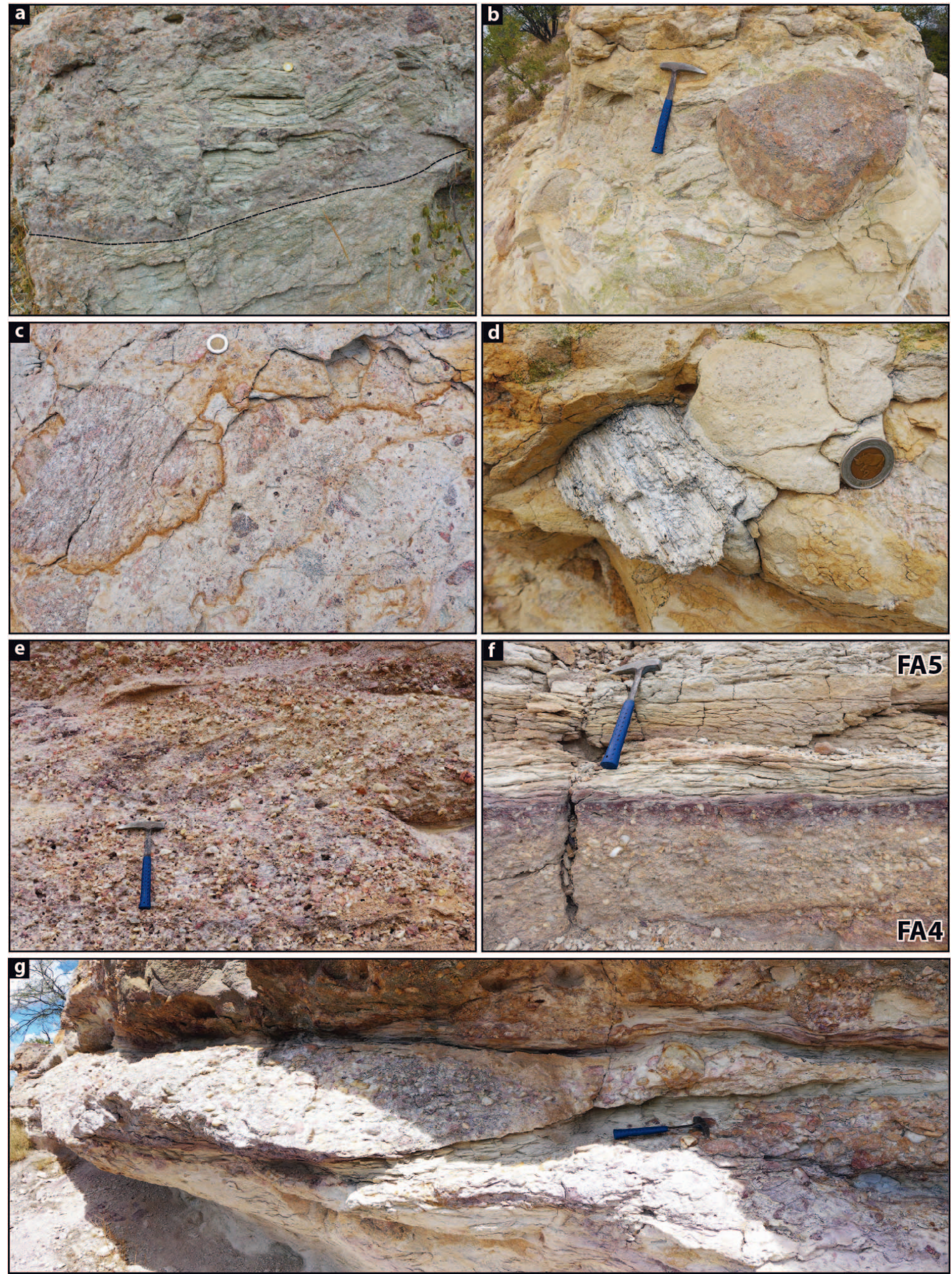

FIG. 6. - Outcrop views of the diamictite (FA3) and the cross-bedded conglomerates (FA4). A) Contact (highlighted by the thin dashed line) between the basement rock and the diamictite (FA3) showing angular clasts ripped up from the immediate underlying basement. B) Diamictite (FA3) observed higher up in the succession, showing a subangular boulder (pink granite) wrapped in a sandy to muddy matrix. C) Close-up view of the diamictite showing granules, pebbles, and cobbles derived from the underlying basement, engulfed by the whitish, sandy-muddy matrix. D) A tree log found in the diamictite. See microphotographs in Figure 7. E) Cross-bedded conglomerate (FA4) bearing abundant well-rounded quartz and quartzite pebbles. F) Contact between the underlying cross-bedded conglomerate (FA4) and the overlying muddy sandstones (FA5), highlighted by a purple, chemically weathered horizon interpreted as a paleosol. G) Lenses of conglomerate (ca. 3-5 $\mathrm{m}$ in width and $1 \mathrm{~m}$ in depth) interpreted as small channel-fill deposit. Note the thin beds of whitish, fine-grained sandstones at the top and bottom of the lens. See Figure 3 for location. 

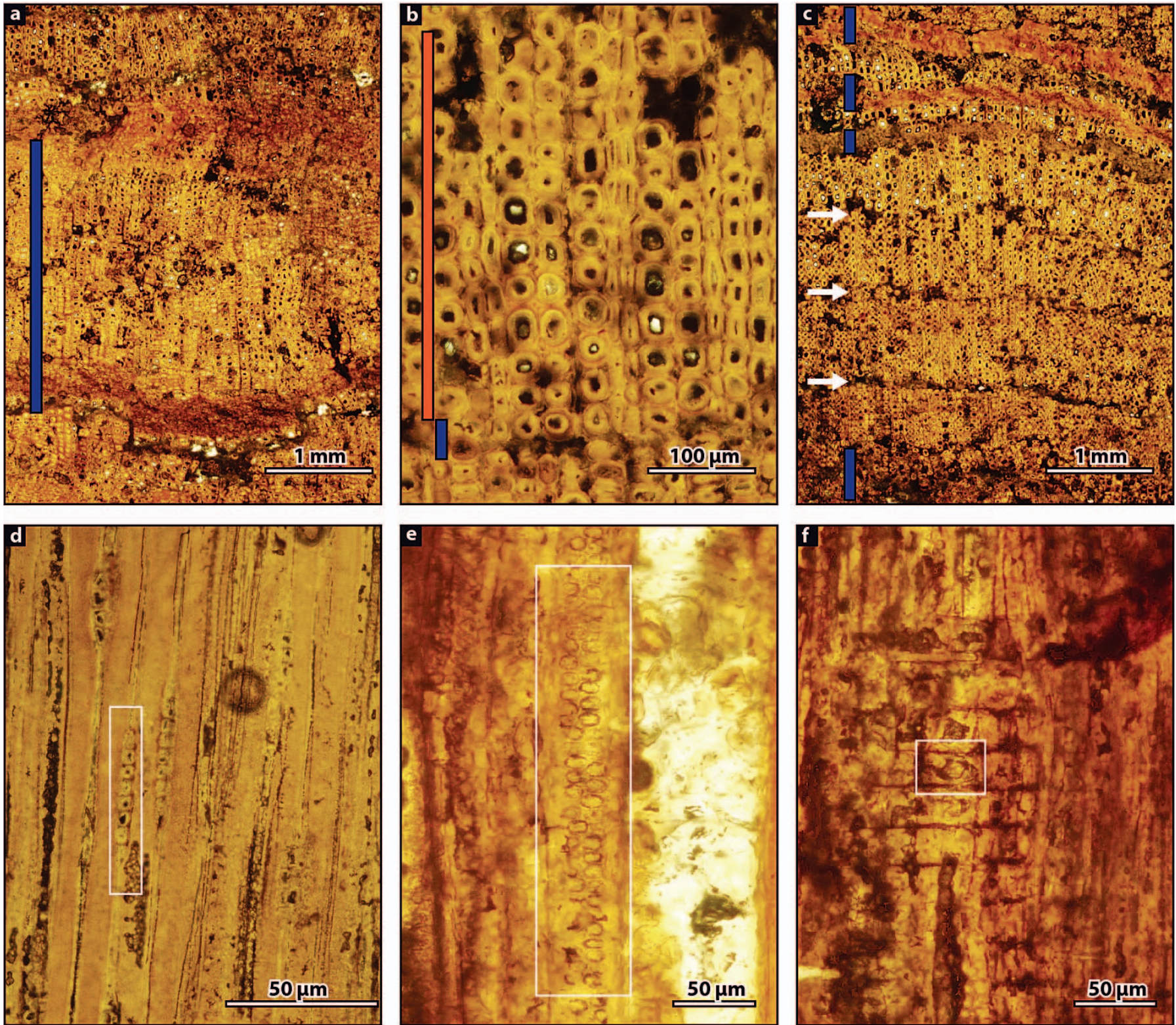

FIG. 7.-Microphotographs of permineralized wood from tree logs sampled in the diamictite unit. A) Transverse section (TS) of the polished wood thin section with a relatively wide growth ring. Dense cells in two bands are the latewood with the broad central band of lighter, larger cells representing the early wood. B) Detail of tracheids in TS; note the thick walls and dark contents in the lumens. C) TS of a wide ring with three horizontal bands of traumatic cells. Note very narrow latewood-earlywood bands at the top. D) Tangential longitudinal section (TLS) with tracheids like vertical tubes and rays in between (box indicates lens of small, rounded parenchyma cells of a ray). Dark contents can be seen in some tracheids. E) TLS tracheid with bordered pits, biseriate, alternate, separate, and contiguous. F) Radial longitudinal section (RLS) showing crossfield with one large simple pit or oopore.

\section{FA4: Cross-Bedded Conglomerate, Alluvial-Fan to Braided Fluvial Deposits}

Description.-This FA unconformably overlies FA2 and FA3 or rests directly on the basement exposed along the paleotopographic highs. FA4 consists of a 3-10-m thick sheet-like unit of clast- to matrix-supported, locally chaotic to mainly cross-bedded conglomerate which shows an overall upward increase in maturity together with a predominance of quartz clasts and a decrease in mean grain size (Figs. 3, 4, 6E-G). The base ( 0.5 to locally $2 \mathrm{~m}$, see $\log 4$ in Fig. 3) of the unit, erosional over the underlying diamictite or well-bedded siltstones, is a clast-supported, polymict conglomerate massive in appearance consisting of subangular to subrounded gneiss pebbles and cobbles and well-rounded quartz and lithic (quartzite) gravels and pebbles (Fig. 5E). Above this chaotic basal layer, FA4 consists of a matrix-supported, cross-bedded monomict (almost $100 \%$ quartz clasts; Fig. 4) conglomerate. The transition from the basal polymict conglomerate, where present, or the underlying units (FA2 and FA3), is marked by a pebble and cobble lag (Fig. 3). The matrix of the monomict conglomerate consists of poorly sorted, medium- to very coarsegrained quartzitic sandstones. Individual tabular beds, decimeters to meters thick, display trough and planar cross-bedding that indicates a mean westward paleoflow direction. Minor internal erosion surfaces forming sediment wedges are common, and flat-topped, concave-upward lenses, 3$5 \mathrm{~m}$ in width and $1 \mathrm{~m}$ in depth, are observed in places (Fig. 6G). 
Discontinuous lenses of horizontally bedded to cross-stratified, poorly sorted coarse-grained sandstones are occasionally interbedded in the conglomerate. The uppermost surface of this conglomerate unit is characterized by a $10-20-\mathrm{cm}$ thick purple, chemically weathered horizon that filled the interstices between the conglomerate gravels and pebbles and stained the sandstone matrix (Fig. 6F).

Interpretation.-The ubiquitous presence of cross-bedding throughout this conglomeratic unit indicates that deposition occurred through tractive currents, the few observed concave-up lenses likely representing channelfill deposits (Fig. 6G) characterized by a high (3 to 5) width/depth ratio. Overall the sequence reflects shallow but relatively wide channels undergoing frequent avulsions pointing toward a gravel-bed braided fluvial environment (Miall 2006). The scarcity of sandstone beds that would reflect sedimentation during low-level stages suggests that the fluvial system remained perennially energetic with only minor flow fluctuations. In such a context, the basal chaotic polymict conglomerate can therefore be interpreted as subaerial debris or hyperconcentrated flow deposits forming an alluvial fan (Miall 2006; Soreghan et al. 2009) and that would mark the onset of the alluvial setting that would have blanketed remnants of the underlying paleotopography. Upsection, an increase in clast maturity coupled with a decrease in clasts of local origin (Figs. 3, 4) indicate a shift of source area and transport distance, the basal polymict conglomerate being mainly locally derived, which confirms the alluvial-fan interpretation, while the overlying monomict conglomerate likely reflects greater transport and sorting, and although not constrained, matches the braidedfluvial interpretation. The intervening lag horizon indicates that winnowing processes operated during an ephemeral interruption in sedimentation. The weathered, purple horizon that characterizes the upper surface of this conglomerate unit (Fig. 6F) is tentatively interpreted here as a paleosol that developed on overbanks after avulsion and temporary abandonment of the alluvial system (Miall 2006).

\section{FA5: Poorly Sorted Muddy Sandstones, Crevasse-Splay Deposits}

Description.-The contact between FA4 and FA5 is sharp but conformable, underlined by the purple horizon shown in Figure 6F. Throughout the Hill succession, FA5 shows a constant thickness of ca. 2-3 $\mathrm{m}$ (Fig. 3) and is made up of poorly sorted muddy sandstones, characterized by either massive or faint planar to ripple cross-laminated beds, $1-10 \mathrm{~cm}$ in thickness (Fig. $6 \mathrm{~F}$ ). Mud chips and granules and small quartz pebbles are abundant, dispersed in the massive intervals (Fig. 8A) In a few instances, contorted, tubular-shaped beds have been observed in the lower half of the unit, at the contact with the underlying cross-bedded conglomerate (Fig. 3). Farther up in the section, alternation between thin (1 $\mathrm{cm})$ sandstone and thicker $(10 \mathrm{~cm})$ siltstone beds shows pervasive tubular disturbance of the lamination pattern, in the form of small vertical tubes (Fig. 8B). These muddy sandstones grade upward into cross-bedded coarse-grained sandstones (FA6; Figs. 3, 8B, C).

Interpretation.-Deposition occurred through the combined action of tractive currents as indicated by the presence of hydrodynamic sedimentary structures (planar and ripple cross-lamination) and thin debris flows (massive intervals bearing dispersed granules). Combined with the fact that this unit lies directly on fluvial deposits, over an intervening paleosol (purple horizon), it is suggested that these facies also represent alluvia deposits, although finer-grained, and are therefore interpreted as the distal to medial segment of crevasse splays or floodplain deposits (Fielding 1984; Ramos et al. 2002; Miall 2006). This crevasse may thus reflect renewal of the fluvial system - after a significant hiatus as evidenced by the paleosol horizon - after its avulsion that abandoned the underlying cross-bedded conglomerate. In such an alluvial context, contorted, tubular-shaped beds may relate to postdepositional gravitational instabilities, possibly occurring along inherited and abandoned channel margins (Fig. 3) that promoted the development of loading, creeping, and slumping; small vertical tubes may represent bioturbation (root systems or burrows). Coarser sandstone beds incrementally stratified in the muddy sandstones and ultimately leading to the coarse-grained sandstones of SU6 (see below) may reflect the progradation of the splay system toward its proximal counterpart (Miall 2006).

\section{FA6: Cross-Bedded Coarse-Grained Sandstones, Braided Deposits or Proximal Crevasse Splays}

Description.-This FA is represented by a 5-10-m-thick, tabular unit which forms the uppermost part of the Hill succession. FA6 consists of extremely poorly sorted, coarse- to very coarse-grained sandstone and granule conglomerate arranged in tabular to lensoidal bodies, 5 to $40 \mathrm{~cm}$ in thickness. This lithofacies is characterized by well-developed trough to planar cross-bedding, indicating a mean westward to southwestward paleoflow (Fig. 8D). Soft-sediment deformation structures (convoluted beds) are common in this lithofacies, where they hinder the observation of primary sedimentary structures (Fig. 8C). Abundant tree-log imprints have been found in these sandstones but remained unidentifiable due to their poor preservation and absence of cellular details.

Interpretation.-The ubiquitous presence of cross-bedding, as well as the lensoidal bodies, individually interpreted as channel fills, indicate that deposition occurred under the action of renewed energetic tractive currents. As transition from the underlying muddy sandstones is gradual, we here suggest that these coarse-grained sandstones either represent the fully developed, proximal segment of the crevasse splay system or, alternatively, the renewal of the fluvial (braided) system after a period of avulsion (Smith et al. 1989). The coarsening- and thickening-upward trend observed in this sedimentary unit reflects a progressive increase in energy, while the presence of convoluted beds suggest that deposition occurred rapidly, and sandstone layers were still water-logged when buried. The presence of abundant land plant debris (trees) indicates that the landscape in at least some of the greater catchment area was forested.

\section{DISCUSSION}

\section{Paleoenvironmental Reconstruction: No Direct Evidence for Glacial} Processes

Throughout the studied section, no striations have been found on clasts which are commonly fine-grained (quartzite, quartz), especially in the conglomerate unit, which bears almost exclusively quartz clasts (FA4), which are prone to preserve glacial striations, or on the substratum. Clasts constituting the coarse-grained facies throughout the studied section are locally and regionally derived. Evidence for glacial processes is therefore arguably lacking in the studied sedimentary succession. It is demonstrated here that the sedimentary succession forming the Hill rather originated from colluvial, lacustrine, and alluvial processes (Fig. 9), in which no direct glacial influence has been conclusively recognized.

The sequence of depositional events that led to the stratigraphic succession observed at the Hill started with the deposition of colluvial (FA1) and mass-flow (FA3) deposits owing to the mechanical disintegration and collapse of a basement rock characterized by a prominent topography (Fig. 9). Concomitantly, laminated siltstone (FA2) was deposited. Accumulation of both coarse (FA1 and FA3) and finer-grained (FA2) sediments that culminated in the deposition of the cross-bedded conglomerate (FA4) eventually led to the blanketing of the paleotopography, followed by the deposition of sheet-like alluvial units (FA5 and FA6). 

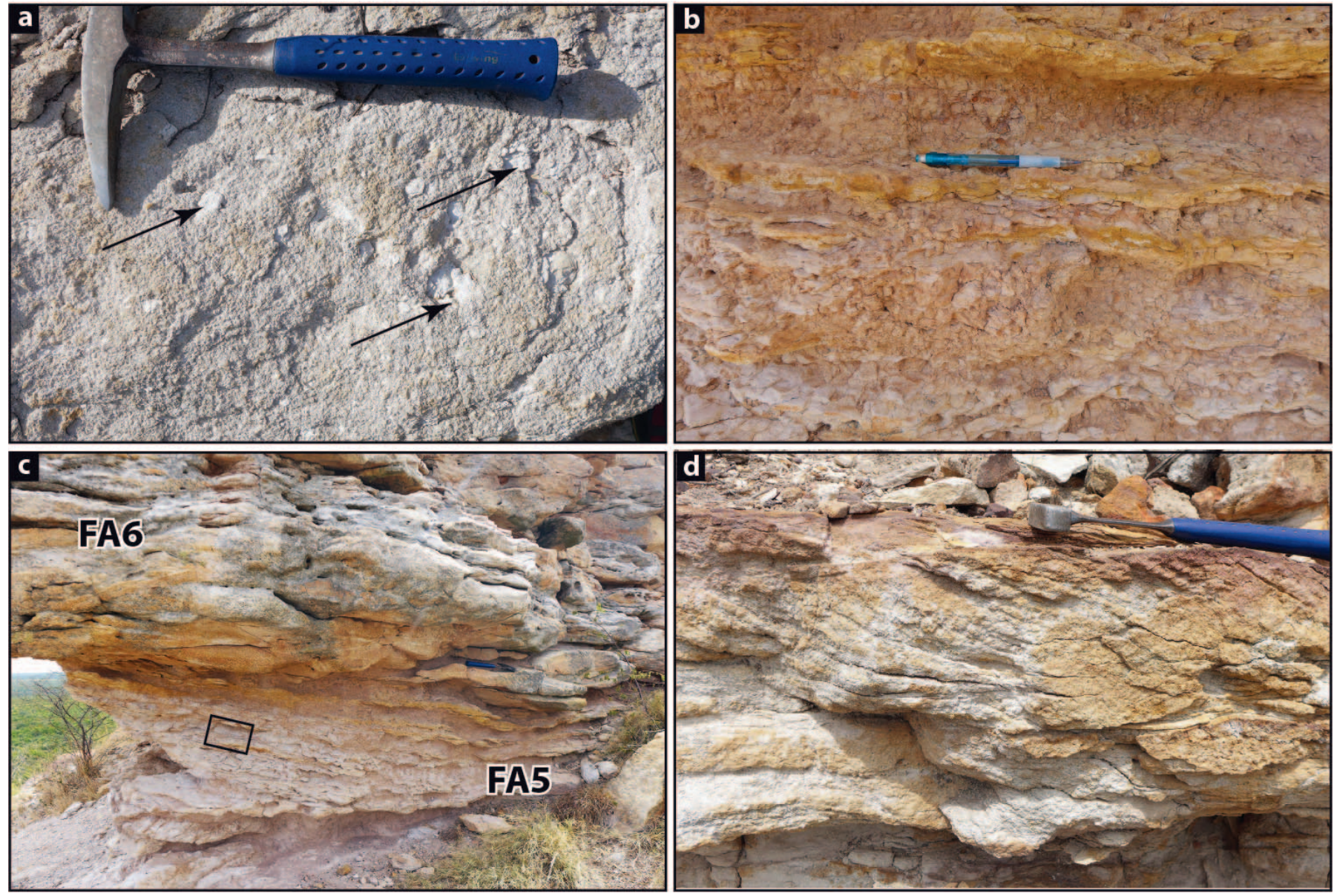

FIG. 8.-A) Close-up view of muddy sandstones (FA5) displaying dispersed mud chips (arrows) and quartz granules. B) Alternation between thin (1 cm) sandstone and thicker $(10 \mathrm{~cm})$ siltstone beds showing pervasive disturbance of the lamination pattern in FA5. C) Gradual transition between muddy sandstones (FA5) and the overlying coarse-grained, cross-bedded sandstones (FA6). The box highlights the position of Part B. D) Details of cross-bedding developed in the coarse-grained sandstones (FA6).

We must however address the fact that although facies observed in the Hill succession arguably lack evidence of glaciogenic processes, we cannot completely rule out the possibility that at least some glaciogenic material was supplied by an ice margin in the greater catchment (inset in Fig. 9). As a matter of fact, studies that tackled deglaciation sedimentary successions in the Quaternary have indeed demonstrated that proglacial deltaic systems may lack any evidence directly diagnostic of glacial processes, despite being fed by meltwater and glaciogenic sediments from retreating ice sheet margins (Nutz et al. 2015; Dietrich et al. 2017, 2018). In the current case study, the presence of laminated fine-grained sediments (FA2) suggest the influence of a seasonal climatic setting and as such may represent varvites (i.e., alternation between cold and warmer seasons; Zolitschka et al. 2015) in periglacial lakes (Catuneanu et al. 2005) although the annual character is not demonstrable here. Also, traumatic rings observed in the wood debris point toward a harsh, possibly cold climate that may have characterized such a periglacial environment. Finally, as trough cross-bedded coarse to conglomeratic sandstones (FA4 and FA6) are undistinguishable from proglacial outwash and fluvioglacial deposits (inset in Fig. 9; Marren $2005)$, it is suggested that an ice margin present in the greater catchment may have supplied fluvioglacial material which permitted the aggradation of such deposits and the subsequent blanketing of the underlying topography.

\section{Implications for the LPIA Ice Sheet Model}

Recent re-evaluation of diamictic successions tied to the LPIA and hitherto interpreted as glaciogenic in South America, Antarctica, and southern Africa indicate that at least some of these facies rather represent alluvial, colluvial, rock-fall, or mass-flow deposits, without any diagnostic glacial signature (Isbell et al. 2001, 2008b; Bordy and Catuneanu 2002; Moxness et al. 2018; Fedorchuck et al. 2018). These studies have facilitated the refinement of both the spatial and temporal extent of the LPIA-related ice sheets or caps over southern Gondwana. Although these successions were deposited through non-glaciogenic processes, they are contemporaneous with demonstrably glaciogenic series deposited in the same or adjacent basins during glacial epochs.

No precise age inference has been obtained from the studied succession: gymnosperm woods recovered from the Hill succession, and reported here for the first time, can unfortunately give only a broad temporal range bracketing the Late Carboniferous and Early Permian. Similarly, the fossil leaf genera identified are wide-ranging and a high-resolution biostratigraphy based on plant evidence is currently lacking in southern Africa. The age of the sediments nevertheless does not represent an unambiguous criterion in attributing the Hill succession to the Dwyka Group, as the latter and its stratigraphic equivalents throughout the Karoo-age basins of southern Africa were most likely deposited diachronously throughout a 


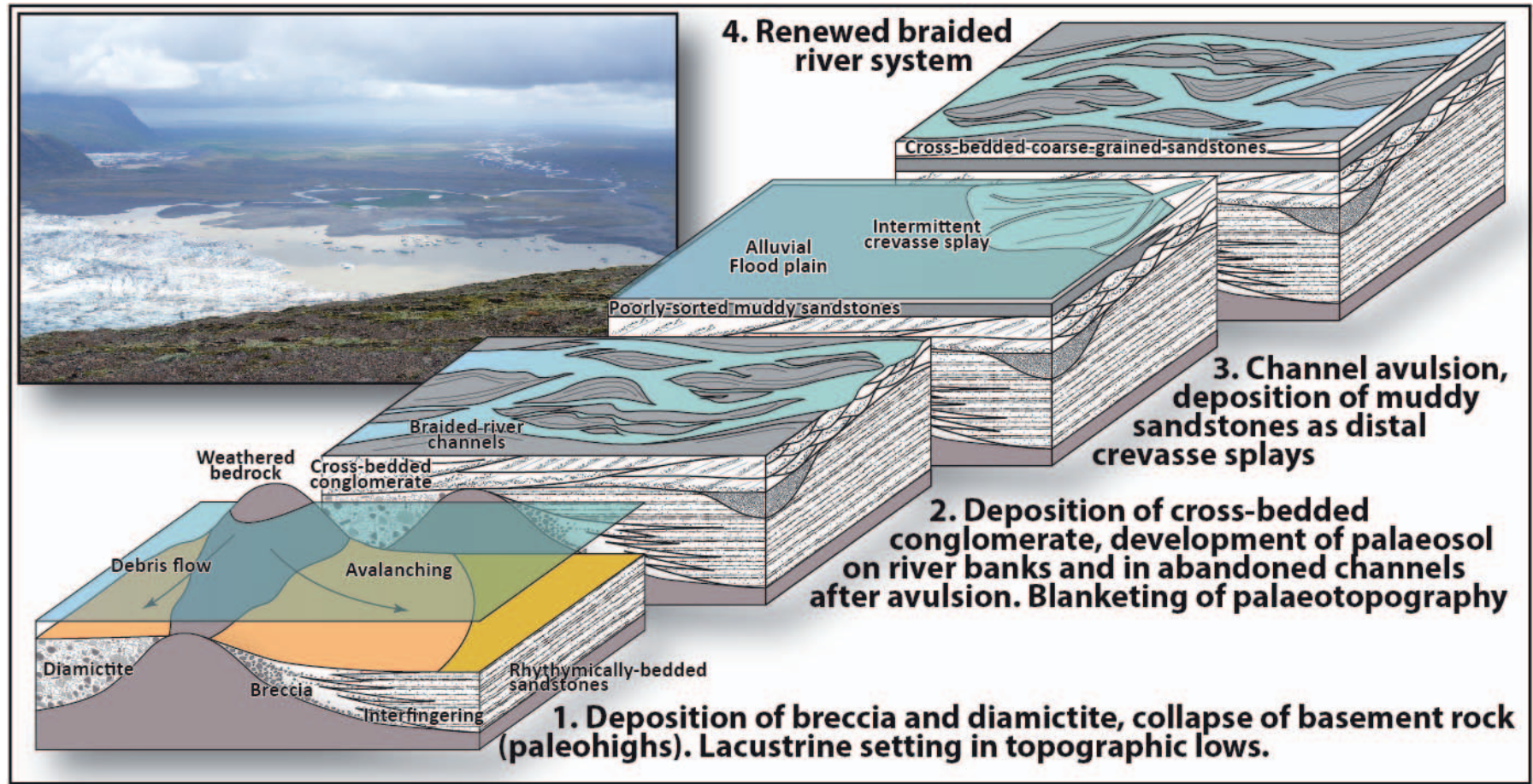

FIG. 9.-Block diagram representing the successive depositional events that led to the formation of the Toutswemogala Hill succession. 1) Deposition of diamictite and breccia facies as a result of destabilization of basement slopes. 2, 3, and 4) Deposition of cross-bedded conglomerate, fine-grained muddy sandstones, and coarse-grained, cross-bedded sandstones in alluvial settings alternating between channel and overbank (crevasse splays) deposits. Inset is a picture of the modern Skaftafell Glacier (Iceland) confined in a bedrock valley and feeding a (proglacial) fluvial system in the background. The ice tongue is ca. $2 \mathrm{~km}$ wide.

time span of several millions of years (e.g., Visser 1990; Catuneanu et al. 1998; Bangert et al. 1999; Stollhofen et al. 2008; Isbell et al. 2008a, 2008b; Fildani et al. 2009; McKay et al. 2015; Griffis et al. 2019). In term of facies, however, the deposits observed in the Hill succession closely resemble those recovered from boreholes at the base of the Karoo succession and attributed to the Dwyka Group in the center of the KKB, as well as in the neighboring Tuli, Ellisras, and Tshipise basins (Fig. 1). These are patchy breccias and/or conglomerates found as irregular pockets on the underlying, irregular basement that essentially lack diagnostic glacial features (Smith 1984; Catuneanu et al. 1998; Bordy and Catuneanu 2002; Bordy 2013). Based on the similar stratigraphic position of the succession described here, we interpret the Hill sediment as belonging to the Dwyka Group. It must however be noted that boreholes drilled near the village of Palapye some $40 \mathrm{~km}$ to the SSW of the study area and in the MmamabulaDibete area, more than a hundred kilometers away to the south (Fig. 10), nevertheless revealed striated pebbles in diamictite that occur in patchy hollows on the pre-Karoo surface, showcasing a spatially restricted presence of continental glaciers (Maufe 1922; Du Toit 1954; Williamson 1996). Hence, the basal stratigraphic succession of the Karoo Supergroup in the eastern side of the KKB in Botswana filling lows of the highly uneven paleotopography consists of predominantly non-glaciogenic, coarse-grained facies originating from colluvial, alluvial, and lacustrine processes, but in which sparse evidence of the presence of glaciers is sporadically encountered. We therefore suggest that in the broader region, spatially restricted valley glaciers occupied local low-lying grounds surrounded by mainly non-glaciated highs, and likely emanated from a peripheral center of glaciation such as the Cargonian Highlands to the east, southeast and south (Fig. 9, inset, and Fig. 10). Similar conclusions were reached by Bond (1952), and Bond and Stocklmayer (1966, and references therein) for the adjacent mid-Zambezi basin of Zimbabwe (northeastern part of the $\mathrm{KKB}$ ), where equivalent depositional facies characterize the base of the Karoo sequence. Ice could have potentially supplied glaciogenic sediments to the Hill succession, giving rise to the "proglacial outwash deposits" aspect of the cross-bedded conglomerate (FA4) and sandstone (FA6) facies. Inferred westward paleocurrents in these units support the hypothesis of an ice spreading center located toward the southeast, over the Cargonian Highlands (Fig. 10). Dropstones observed in mudstones in the center of the KKB (Smith 1984; Bordy 2013) may therefore reflect a deeper glaciomarine setting possibly fed by the aforementioned glaciers through an ice shelf or a calving front. Such a paleogeographical configuration may account for the total lack of glaciogenic sediments in the Hill succession as well as the paucity of conclusive diagnostic criteria in the KKB and in the small Karoo-age basins of northern South Africa (Tuli, Ellisras, and Tshipise; Catuneanu et al. 2005, their Fig. 8). It may, however, be suggested that the paleotopography sculped into the bedrock before deposition of the Dwyka Group originated partly from direct glacial abrasion before basin subsidence that led to the initiation of the KKB, permitting deposition of the Dwyka sediments and preservation of fragmented ice masses over remaining highlands (see also Visser 1990).

This sedimentological context strongly departs from the one characterizing the southwestern part of the KKB in Botswana and Namibia (the Gemsbok and Aranos basins; Fig. 10), where conventional glaciogenic diamictites associated with striated pavements similar to those seen in the Main Karoo Basin in South Africa are abundant (e.g., Du Toit 1954; Boocock and van Stralen 1962; Grill 1997; Key et al. 1998, and references therein). Important ice masses probably flowed from the nearby Cargonian Highlands carving into the bedrock as they moved through deep and large valleys, like the Hotazel and Tshipise ones (Fig. 10; Visser 1987), before spreading into the basin. The dichotomy between these two basinal configurations may have originated either from a different tectonic (differential-diachronous subsidence linked with the initiation of the KKB and favoring ice flow) or paleogeographic (distance to glaciated highlands, paleolatitude) settings, but this has yet to be explored. 


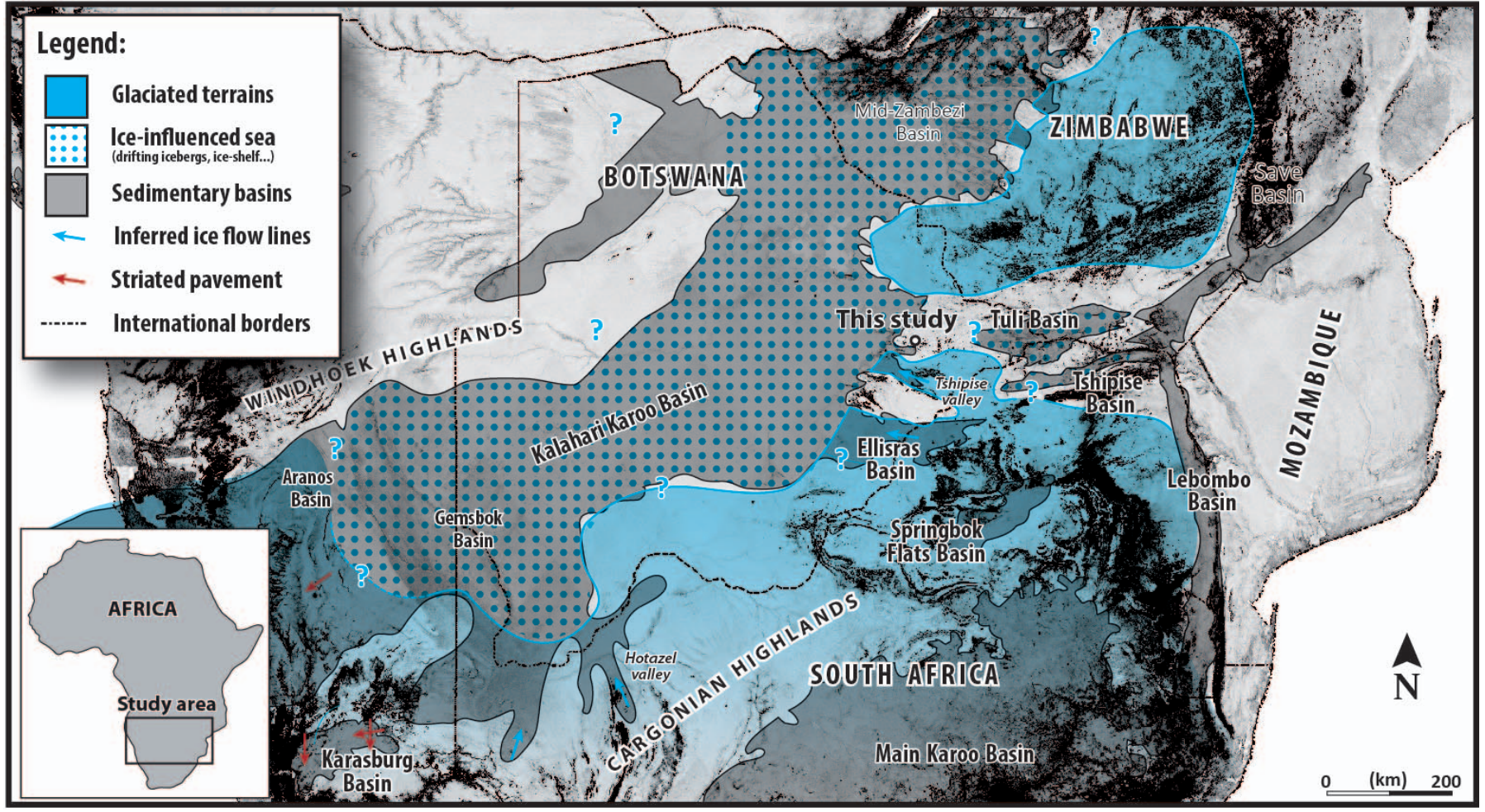

FIG. 10.-Proposed paleogeographic reconstruction of the Dwyka ice masses over the Kalahari-Karoo Basin (KKB) and surrounding highlands and basins during Dwyka time, based on the present contribution and those of others. Visser (1987) and Catuneanu et al. (2005) for the extent of the Karoo-aged basins; Smith (1984) and Bordy (2013) for the Dwyka succession in the center of the KKB; Bond (1952) and Bond and Stocklmayer (1966) for the mid-Zambezi; Du Toit (1954), Boocock and van Stralen (1962), Grill (1997), and Key et al. (1998) and references therein for the Aranos and Gemsbok basins; Martin (1981) for the Karasburg; Du Toit (1954), Faure et al. (1996), Williamson (1996), Catuneanu and Bordy (2002), Catuneanu et al. (2005), and Bordy (2018) for the Tuli, Ellisras, and Tshipise basins although no consensus on the nature of the Dwyka Group seems to emerge here; Maufe (1922) for glacial deposits in the western branch of the Tshipise valley. The Hotazel and Tshipise valleys are from Visser (1987). Note that the ice configuration over the Main Karoo Basin of South Africa, the Save and Lebombo basins, as well as the northern side of the KKB like the Windhoek Highlands is beyond the scope of the paper, and therefore no reconstruction is here proposed.

\section{CONCLUSION}

A 30-50-m thick siliciclastic succession has been investigated in the southeastern part of the Kalahari-Karoo Basin of Botswana. This succession, dominated by coarse-grained facies (diamictite, conglomerate, breccia), is commonly attributed to the glaciogenic Dukwi Formation tied to the Late Paleozoic Ice Age. By means of a new, detailed lithofacies analyses, we revise the previous depositional model and interpret the basal breccia, the overlying well-bedded siltstones, and the matrix-supported diamictite (originally interpreted as tillite), as scree, lacustrine, and massflow deposits, respectively. This study demonstrates the lack of diagnostic criteria for glacial processes in diamictite facies, with no striated clasts or pavement having being found in this coarse and/or massive deposit and the underlying basement also lacking evidence of glacial processes. Upsection, cross-bedded conglomerate and sandstones and muddy sandstones likely represent alluvial deposits.

Fragmentary fossil leaves have been identified as Glossopteris, Gangamopteris, and either Noeggerathiopsis or Palaeovittaria. Permineralized wood from tree logs collected in the diamictite has been identified as Megaporoxylon. This fossil association indicates an upper Carboniferous to lower Permian age for these deposits which, together with the stratigraphic position of the studied succession, suggests that these deposits form part of the Dukwi Formation, a stratigraphic equivalent of the glaciogenic Dwyka Group of the Main Karoo Basin of South Africa tied to the Late Paleozoic Ice Age. The correlation of the Toutswemogala Hill succession with the LPIA deposits in South Africa raises the question of the extent of the LPIA glaciers in the region. Although initially envisioned as a continuous ice mass covering most of southern Gondwana, our findings support the emerging view that the LPIA ice mass was in fact fragmented, covering only patches of southern Gondwana.

\section{ACKNOWLEDGMENTS}

The authors are grateful to the two reviewers Chris Fielding and John Isbell as well as associate editor Dustin Sweet and co-editor Gary Hampson, whose useful and encouraging comments and suggestions led to the improvement of the paper. Thomas Gyomlai is thanked for his assistance during the field mission. The field-work activities have been funded by BIUST (Botswana International University of Science \& Technology) Initiation Grant P00010/ 2016 to $\mathrm{FF}$

\section{REFERENCES}

ALDISS, D.T., 1991, The Motloutse Complex and the Zimbabwe Craton/Limpopo Belt transition in Botswana: Precambrian Research, v. 50, p. 89-109.

Anderson, A.M., and McLachlan, I.R., 1976, The plant record in the Dwyka and Ecca Series (Permian) of the south-western half of the Great Karroo Basin, South Africa: Palaeontologia Africana, v. 19, p. 31-42.

Anderson, J.M., AND Anderson, H.M., 1985, Palaeoflora of Southern Africa: Prodromus of South African megafloras, Devonian to Lower Cretaceous: Rotterdam, A.A. Balkema, $423 \mathrm{p}$

BAngert, B., AND BAmford, M.K., 2001, Pycnoxylic woods from the Carboniferous Permian Dwyka of southern Namibia: Palaeontologia Africana, v. 37, p. 13-23.

Bangert, B., Stollhofen, H., Lorenz, V., And Armstrong, R., 1999, The geochronology and significance of ash-fall tuffs in the glaciogenic Carboniferous-Permian Dwyka Group of Namibia and South Africa: Journal of African Earth Sciences, v. 29, p. 33-49. 
Bechstädt, T., Jäger, H., Spence, G., and Werner, G., 2009, Late Cryogenian (Neoproterozoic) glacial and postglacial successions at the margin of the Congo Craton, northern Namibia: facies, palaeogeography and hydrocarbon perspective, in Craig, J., Thurow, J., Thusu, B., Whitham, A., and Abutarruma, Y., eds., Global Neoproterozoic Petroleum Systems: The Emerging Potential in North Africa: Geological Society of London, Special Publication 326, p. 255-287.

Bell, T., Cooper, A.K., Solheim, A., Todd, B.J., Dowdeswell, J.A., Canals, M., Jakobsson, M., Dowdeswell, E.K., and Hogan, K.A., 2016, Glossary of glaciated continental margins and related geoscience methods: in Dowdeswell, J.A., Canals, M., Jakobsson, M., Todd, B.J., Dowdeswell, E.K., and Hogan, K.A., eds., Atlas of Submarine Glacial Landforms: Geological Society of London, Memoir 46, p. 555-574.

Bond, G., 1952, Evidence of glaciation in the lower part of the Karroo system in southern Rhodesia: South Africa Geological Society, Transactions and Proceedings, v. 55, p. 1 11

Bond, G., AND StockLmayer, V.R.C., 1966, Possible ice-margin fluctuations in the Dwyka series in Rhodesia: Palaeogeography, Palaeoclimatology, Palaeoecology, v. 3, p. $433-$ 446

Boocock, C., And van Stralen, O.J., 1962, Notes on the Geology and Hydrogeology of the Central Kalahari Region, Bechuanaland Protectorate: South Africa Geological Society, Transactions and Proceedings, v. 65, p. 125-171.

Bordy, E.M., 2013, Sedimentology of the Permo-Carboniferous glacial deposits (Dwyka Group, Karoo Supergroup) in Botswana: The 24th Colloquium of African Geology, January $8-14$, Addis Ababa.

BordY, E.M., 2018, Lithostratigraphy of the Tshidizi Formation (Dwyka Group, Karoo Supergroup), South Africa: South African Journal of Geology, v. 121, p. 109-118.

Bordy, E.M., and Catuneanu, O., 2002, Sedimentology of the Beaufort-Molteno Karoo fluvial strata in the Tuli Basin, South Africa: South African Journal of Geology, v. 105, p. $51-66$

Catuneanu, O., 2004, Basement control on flexural profiles and the distribution of foreland facies: the Dwyka Group of the Karoo Basin, South Africa: Geology, v. 32, p. 517-520. Catuneanu, O., Hancox, P.J., and Rubidge, B.S., 1998, Reciprocal flexural behaviour an contrasting stratigraphies: a new basin development model for the Karoo retroarc foreland system, South Africa: Basin Research, v. 10, p. 417-439.

Catuneanu, O., Wopfner, H., Eriksson, P.G., Cairncross, B., Rubidge, B.S., Smith, R.M.H., AND Hancox, P.J., 2005, The Karoo basins of south-central Africa: Journal of African Earth Sciences, v. 43, p. 211-253.

Caron, V., MahieuX, G., Ekomane, E., Moussango, P., and Babinski, N., 2011, One, two or no record of late Proterozoic glaciation in South-East Cameroon?: Journal of African Earth Sciences, v. 59, p. 111-124.

Chaloner, W.G., and Creber, G.T., 1990, Do fossil plants give a climatic signal? Geological Society of London, Journal, v. 147, p. 343-350.

Craddock, J.P., Ojakandas, R.W., Malone, D.H., Konstantinou, A., Mory, A., Bauer, W. Thomas, R.J., Craddock, A.S., Pauls, K., Zimmermann, U., Botha, G., Rochas-Compos, A., dos Santos, P.R., Tohver, E., Riccomini, C., Martin, J., Redfern, J., Horstwood, M., and Gehrels, G., 2019, Detrital zircons of Permo-Carboniferous glacial diamictites across Gondwana: Earth-Science Reviews, v. 192, p. 285-316.

Dietrich, P., Ghienne, J.-F., Schuster, M., Lajeunesse, P., Nutz, A., Deschamps, R, Roquin, C., AND Duringer, P., 2017, From outwash to coastal systems in the PortneufForestville deltaic complex (Québec North Shore): anatomy of a forced regressive deglacial sequence: Sedimentology, v. 64, p. 1044-1078.

Dietrich, P., Ghienne, J.-F., Lajeunesse, P., Normandeau, A., Deschamps, R., and Razin, P, 2018, Deglacial sequences and glacio-isostatic adjustment: Quaternary compared with Ordovician glaciations in Le Heron, D.P., Hogan, K.A., Phillips, E.R., Huuse, M. Busfield, M.E., and Graham, A.G.C., Glaciated Margins: The Sedimentary and Geophysical Archive: Geological Society of London, Special Publication 475.

Dietrich, P., AND Hofmann, A., in press Ice-margin fluctuation sequences and grounding zone wedges: the record of the Late Paleozoic Ice Age in the Eastern Karoo Basin (Dwyka Group, South Africa): The Depositional Record,

DOWDESWELL, J.A., HAMBrey, M.J., AND WU, R, 1985, A comparison of clast fabric and shape in late Precambrian and Modern glacigenic sediments: Journal of Sedimentary Petrology, v. 55, p. 691-704.

Du Tort, A.L., 1954, The Geology of South Africa (S.H. Haughton): London, Oliver and Boyd, $611 \mathrm{p}$.

Eyles, N., AND JANUSZACK, N., 2007, Syntectonic subaqueous mass flows of the Neoproterozoic Otavi Group, Namibia: Where is the evidence of global glaciation? Basin Research, v. 19, p. 179-198.

Faure, K., Armstrong, R.A., Harris, C., and Willis, J.P., 1996, Provenance of mudstones in the Karoo Supergroup of the Ellisras basin, South Africa: geochemical evidence: Journal of African Earth Sciences, v. 23, p. 189-204

FedorchuK, N.D., Isbell, J.L., Griffis, N.P., Montañez, I.P., Vesely, F.F., Iannuzzi, R., Mundil, R., Yin, Q.-Z., Pauls, K.N., and Rosa, E.L.M., 2018, Origin of paleovalleys on the Rio Grande do Sul Shield (Brazil): implications for the extent of late Paleozoic glaciation in west-central Gondwana: Palaeogeography, Palaeoclimatology, Palaeoecology, v. 531

FERGUSON, D.K., 2005, Plant taphonomy: ruminations on the past, the present, and the future: Palaios, v. 20 , p. $418-428$

FIELDING, C.R., 1984, Upper delta plain lacustrine and fluviolacusrine facies from the Westphalian of the Durham coalfield, NE England: Sedimentology, v. 31, p. 547-567.
Fielding, C.R., Frank, T.D., And Isbell, J.L., 2008, Resolving the Late Paleozoic Ice Age in Time and Space: Geological Society of America, Special Paper 441, $355 \mathrm{p}$.

Fildani, A., Weislogel, A., Drinkwater, N.J., McHargue, T., Tankard, A., Wooden, J., Hodgson, D., and Flint, S., 2009, U-Pb zircons from the southwestern Karoo Basin, South Africa: implications for the Permian-Triassic boundary: Geology, v. 37, p. 719 722 .

Froenlich, D.C., 2011, Mass angle of repose of open-graded rock riprack: Journal of Irrigation and Drainage Engineering, v. 137, p. 454-461.

Gastaldo, R.A., and DemKo, T.M., 2011, The relationship between continental landscape evolution and the plant-fossil record: long term hydrologic controls on preservation, in Allison, P.A., and Bottjer, D.J., eds., Taphonomy: Process and Bias through time: Topics in Geobiology, Second Edition, Springer, v. 32, p. 249-285.

GonzÁlez-Bonorino, G., AND Eyles, N., 1995, Inverse relation between ice extent and the late Paleozoic glacial record of Gondwana: Geology, v. 23, p. 1015-1018.

GoudiE, A.S., 2004, Encyclopaedia of Geomorphology: London, Routledge, 1202 p.

Griffis, N.P., Mundil, R., Montañez, I.P., Isbell, J., Fedorchuk, N.D., Linol, B., Iannuzzı, R., Vesely, F., Mottin, T., da Rosa, E., Keller, B., and Zin, Q.-Z., 2019, Deciphering the timing of the LPIA in southern Gondwana using U-Pb CA-TIMS geochronology: European Geosciences Union General Assembly, Vienna.

Grill, H., 1997, The Permo-Carboniferous glacial to marine Karoo record in southern Namibia: sedimentary facies and sequence stratigraphy: Beringeria, v. 19, 99 p.

Guillocheau, F., 2018, Les "rifts" Karoo en Afrique: leur signification à l'échelle du Gondwana et de la subduction de la Panthalassa: Géochronique, v. 145, p. 52-56.

Haughton, S.H., 1963, The stratigraphic history of Africa south of the Sahara: Edinburg, Oliver and Boyd, 365 p.

Herbert, C.T., And Compton, J.S., 2007, Depositional environments of the lower Permian Dwyka diamictite and Prince Albert shale inferred from the geochemistry of early diagenetic concretions, southwest Karoo Basin, South Africa: Sedimentary Geology, v. 194 , p. $263-277$

Isbell, J.L., Miller, M.F., Babcock, L.E., AND Hasiotis, S.T., 2001, Ice-marginal environmental and ecosystem prior to initial advance of the late Palaeozoic ice sheet in the Mount Butters area of the central Transantarctic Mountains, Antarctica: Sedimentology, v. 48, p. 953-970.

Isbell, J.L., Cole, D.I., And Catuneanu, O., 2008a, Carboniferous-Permian glaciation in the main Karoo Basin, South Africa: stratigraphy, depositional controls, and glacial dynamics, in Fielding, C.R., Frank, T.D., and Isbell, J.L., eds., Resolving the Late Paleozoic Ice Age in Time and Space: Geological Society of America, Special Publication 441, p. 71-82

IsbelL, J.L., Koch, Z.J., Szablewski, G.M., AND Lenaker, P.A., 2008b, Permian glacigenic deposits in the Transantarctic Mountains, in Fielding, C.R., Frank, T.D., and Isbell, J.L., eds., Resolving the Late Paleozoic Ice Age in Time and Space: Geological Society of America, Special Publication 441, p. 59-70.

Isbell, J.L., Henry, L.C., Gulbranson, E.L., Limarino, C.O., Fraiser, M.L., Koch, Z.J., Ciccioli, P.L., And Dineen, A.A., 2012, Glacial paradoxes during the late Paleozoic ice age: evaluating the equilibrium line altitude as a control on glaciation: Gondwana Research, v. 22, p. 1-19.

Johnson, M., van Vuuren, C.J., Visser, J.N.J., Cole, D.I., Wickens, H.V., Christie, A.D.M., RoberTs, D.L., AND BRANDL, G., 2006, Sedimentary rocks of the Karoo Supergroup, in Johnson, M.R., Anhaeusser, C.R., and Thomas, R.J., eds., Geology of South Africa: Johannesburg, Council for Geoscience, p. 461-500.

Kennedy, K., Eyles, N., And Broughton, D., 2019, Basinal setting and origin of thick (1.8 $\mathrm{km}$ ) mass-flow dominated Grand Conglomérat diamictites, Kamoa, Democratic Republic of Congo: resolving climate and tectonic controls during Neoproterozoic glaciation: Sedimentology, v. 66, p. 556-589.

Key, R.M., And Golding, A., 1994, The geology of the Topisi area: a report on the geology of quarter degreesheet 2227A: Bulletin Series, The Geological Survey Department of Botswana, Bulletin 38

Key, R.M., Tidy, J., McGeorge, I., Aitken, G., Cadman, A., and Anscombe, J., 1998, The Lower Karoo Supergroup of the southwestern part of the Gemsbok Sub-basin of the Kalahari Basin, Botswana: South Africa Journal of Geology, v. 101, p. 225-236.

KRÄUSEL, R., 1956, Hölzer aus dem südlichen Gebiet de Karoo Schichten Südwest-Afrika: Senckenbergiana Lethaia, Routledge, v. 37, p. 447-453.

KRÄUSEL, R., AND RANGE, P., 1928, Beitäge zur Kenntnis der Karruformation DeutschSüdwest-Afrika: Beitäge zur geologischen Erforschung der Deutschen Schutzgebiete, v. 20, p. $1-54$.

Le Heron, D.P., Tofaif, S., Vandyk, T., and Ali, D.O., 2017, A diamictite dichotomy: glacial conveyor belts and olistostromes in the Neoproterozoic of Death Valley, California, USA: Geology, v. 45, p. 31-34

López-Gamundi, O.R., AND Buators, L.A., 2010, Late Paleozoic Glacial events and postglacial transgressions in Gondwana: Geological Society of America, Special Pape $468,218 \mathrm{p}$.

Mapeo, R.B.M., Ramokate, L.V., Armstrong, R.A., and Kampunzu, A.B., 2004, U-Pb zircon age of the upper Palapye group (Botswana) and regional implications: Journal of African Earth Sciences, v. 40, p. 1-16

Marren, P.M., 2005, Magnitude and frequency in proglacial rivers: a geomorphological and sedimentological perspective: Earth-Science Reviews, v. 70, p. 203-251.

Martin, H., 1981, The Late Palaeozoic Dwyka Group of the Karasburg Basin, Namibia, in Hambrey, M.J., and Harland, W.B., eds., Earth's pre-Pleistocene Glacial Record: New York, Cambridge University Press, p. 67-70. 
Maufe, H.B., 1922, The Dwyka Tillite near Palapye, Bechuanaland Protectorate: South African Geological Society, Transactions and Proceedings, v. 25, p. 68-71.

McKay, M.P., Weislogel, A.L., Fildani, A., Brunt, R.L., Hodgson, D.M., and Flint, S.S , 2015, U-Pb zircon tuff geochronology from the Karoo Basin, South Africa: implication of zircon recycling on stratigraphic age controls: International Geology Review, v. 57, p. 393-410.

Modie, B.N., 2002, Glacial Records in Botswana: 16th International Sedimentological Congress, Cape Town, South Africa.

Modie, B.N., 2007, The palaeozoic palynostratigraphy of the Karoo supergroup and palynofacies insight into palaeoenvironmental interpretations, Kalahari Karoo Basin, Botswana [PhD Thesis]: Université de Bretagne Occidentale, $317 \mathrm{p}$.

Modie, B.N., AND Le Hérissé, A., 2009, Late Paleozoic palynomorph assemblages from the Karoo Supergroup and their potential for biostratigraphic correlation, Kalahari Karoo Basin, Botswana: Bulletin of Geosciences, v. 1122, p. 337-358.

Miall, A.D., 2006, The Geology of Fluvial Deposits: Sedimentary Facies, Basin Analysis, and Petroleum Geology: Berlin, Springer, 598 p.

MonCRIEFF, A.C., 1989, Classification of poorly-sorted sedimentary rocks: Sedimentary Geology, v. 65, p. 191-194.

Moxness, L.D., Isbell, J.L., Pauls, K.N., Limarino, C.O., and Schencman, J., 2018, Sedimentology of the mid-Carboniferous fill of the Olta paleovalley, eastern Paganzo Basin, Argentina: implications for glaciation and controls on diachronous deglaciation in western Gondwana during the late Paleozoic Ice Age: Journal of South American Earth Sciences, v. 84 , p. $127-148$.

Mulder, T., And Alexander, J., 2001, The physical character of subaquaeous sedimentary density flows and their deposits: Sedimentology, v. 48, p. 269-299.

Nutz, A., Ghienne, J.-F., Schuster, M., Dietrich, P., Roquin, C., Hay, M.B., Bouchette, F, And Cousineau, P.A., 2015, Forced regressive deposits of a deglaciation sequence: example from the late Quaternary succession in the Lake St. Jean basin (Québec, Canada): Sedimentology, v. 62, p. 1573-1610.

Plumstead, E.P., 1969, Three thousand million years of plant life in Africa: Alex. L. du Toi Memorial Lecture, No. 11, annexure to Transactions of the Geological Society of South Africa, v. 72, $72 \mathrm{p}$

Prior, D.B., AND BoRnhold, B.D., 1988, Submarine morphology and processes of fjord fan deltas and related high-gradient systems: modern examples from British Columbia, in Nemec, W., and Steel, R.J., eds., Fan Deltas: Sedimentology and Tectonic Settings: Blackie and Sons, p. 125-143.

Pysklywec, R.N., And Mitrovica, J.X., 1999, The role of subduction-induced subsidence in the evolution of the Karoo Basin: The Journal of Geology, v. 107, p. 155-164.

Ramos, E., Busquets, P., AND Vergés, J., 2002, Interplay between longitudinal fluvial and transverse alluvial fan systems and growing thrusts in a piggyback basin (SE Pyrenees): Sedimentary Geology, v. 146, p. 105-131.

SCHEFFLER, K., 2004, Reconstruction of sedimentary environment and climate conditions by multi-geochemical investigations of late Palaeozoic glacial to postglacial sedimentary sequences from SW-Gondwana [Ph.D. Thesis]: University of Bonn, $243 \mathrm{p}$.
Smith, N.D., Cross, T.A., Dufficy, J.P., And Clough, S.R., 1989, Anatomy of an avulsion: Sedimentology, v. 36, p. 1-23.

SмITH, R.A., 1984, The lithostratigraphy of the Karoo Supergroup in Botswana: Geological Survey of Botswana, Bulletin, p. 239-241

SoHn, Y.K., 2000, Depositional processes of submarine debris flows in the Miocene fan Deltas, Pohang Basin, SE Korea with special reference to flow transformation: Journal of Sedimentary Research, v. 70, p. 491-503.

Soreghan, G.S., Soreghan, M.J., Sweet, D.E., and Moore, K.D., 2009, Hot fan or cold outwash? Hypothesized proglacial deposition in the upper Paleozoic Cutler Formation, Western Tropical Pangea: Journal of Sedimentary Research, v. 79, p. 495-522.

Stollhofen, H., Werner, M., Stanistreet, I.G., and Armstrong, R.A., 2008, Single-zircon $\mathrm{U}-\mathrm{Pb}$ dating of Carboniferous-Permian tuffs, Namibia, and the intercontinental deglaciation cycle framework, in Fielding, C.R., Frank, T.D., and Isbell, J.L., eds., Resolving the Late Paleozoic Ice Age in Time and Space: Geological Society of America, Special Publication 441, p. 83-96.

Vesely, F.F., Rodrigues, M.C.N.L., da Rosa, E.L.M., Amato, J.A., Trzaskos, B., Isbell, J.L., AND FedorchuK, N.D., 2018, Recurrent emplacement of non-glacial diamictite during the Late Paleozoic Ice Age: Geology, v. 46, p. 615-618.

VISSER, J.N.J., 1987, The palaeogeography of part of southwestern Gondwana during the Permo-Carboniferous glaciation: Palaeogeography, Palaeoclimatology, Palaeoecology, v. 61, p. 205-219

VISSER, J.N.J., 1989, The Permo-Carboniferous Dwyka formation of southern Africa deposition by a predominantly subpolar marine ice sheet: Palaeogeography, Palaeoclimatology, Palaeoecology. v. 70, p. 377-391.

VISSER, J.N.J., 1990, The age of the late Palaeozoic glacigene deposits in southern Africa: South African Journal of Geology, v. 93, p. 366-375.

VISSER, J.N.J., 1994, The interpretation of massive rainout and debris-flow diamictites from the glacial marine environment, in Deynoux, M., Miller, J.M.G., Domack, E.W., Eyles, N., Fairchild, I.J., and Young, G.M., eds., Earth's Glacial Record: Cambridge University Press, p. 83-94.

VISSER, J.N.J., 1997, Deglaciation sequences in the Permo-Carboniferous Karoo and Kalahari basins of southern Africa: a tool in the analysis of cyclic glaciomarine fills: Sedimentology, v. 44, p. 507-521.

Williamson, I.T., 1996, The Geology of the Mmamabula and Dibete district, south east Botswana: Geological Survey of Botswana, District Memoir

Zavala, C., Arcuri, M., Di Meglio, M., Gamero, H., and Contreras, C., 2010, A genetic facies tract for the analysis of sustained hyperpycnal flow deposits, in Slatt, M., and Zavala, C., eds., Sediment Transfer from Shelf to Deep Water: Revisiting the Delivery System: American Association of Petroleum Geologists, Studies in Geology, v. 61, p. $1-$ 21.

Zolitschio, B., Francus, P., Ojala, A.E.K., and Schimmelmann, A., 2015, Varves in lake sediments: a review: Quaternary Science Reviews, v. 117, p. 1-41.

Received 26 March 2019; accepted 25 June 2019. 
Queries for sedp-89-09-01

This manuscript/text has been typeset from the submitted material. Please check this proof carefully to make sure there have been no font conversion errors or inadvertent formatting errors. Allen Press. 